\title{
Structural glaciology of the fast-moving Jakobshavn Isbræ, Greenland, compared to the surging Bering Glacier, Alaska, U.S.A.
}

\author{
Helmut Mayer, ${ }^{1,2}$ Ute Christina Herzfeld ${ }^{1,2}$ \\ ${ }^{1}$ Geomathematik, Fachbereich Geographie/Geowissenschaften, Universität Trier, D-54286 Trier, Germany \\ ${ }^{2}$ Institute of Arctic and Alpine Research, University of Colorado, Boulder, CO 80309-0450, U.S.A.
}

\begin{abstract}
Crevasse patterns revealing mostly brittle deformation on glacier surfaces are analyzed based on video images collected during systematic overflights of Jakobshavn Isbræ, West Greenland, the Earth's continuously fastest moving ice stream, in 1996 and 1997. Crevasse patterns on the surface of the central ice stream are distinct. All crevasses are closed, the surface appears rather smooth. Towards the margins, typical shear patterns with conjugate shears and still-closed crevasses prevail, curved patterns indicate the bending of crevasse lines into the flow direction. Outward from this zone different patterns of open crevasses occur. This suite of patterns is compared to similar data collected over Bering Glacier, Alaska, U.S.A., during its recent surge from 1993-95. There a number of patterns of mostly open crevasses is characteristic: parallel crevasses, two-directional orthogonal open crevasses, arrays of wavy crevasses, en-échelon crevasses. These patterns of the surging glacier are completely different from those of the fast-moving ice stream indicating different underlying kinematics and dynamics.
\end{abstract}

\section{INTRODUCTION}

In characterizing glaciers as dynamical systems, the easiest approach is to distinguish them by their velocity and classify them into slow-moving and fast-moving glaciers. Surge glaciers, moving slowly most of the time and accelerating to 10 100 times their normal velocity during a surge, may be considered a transitional class between slow-moving and fastmoving ice, but have characteristically different dynamics. This is apparent in surface structures because at any time the crevasse patterns reflect the state of deformation (strain

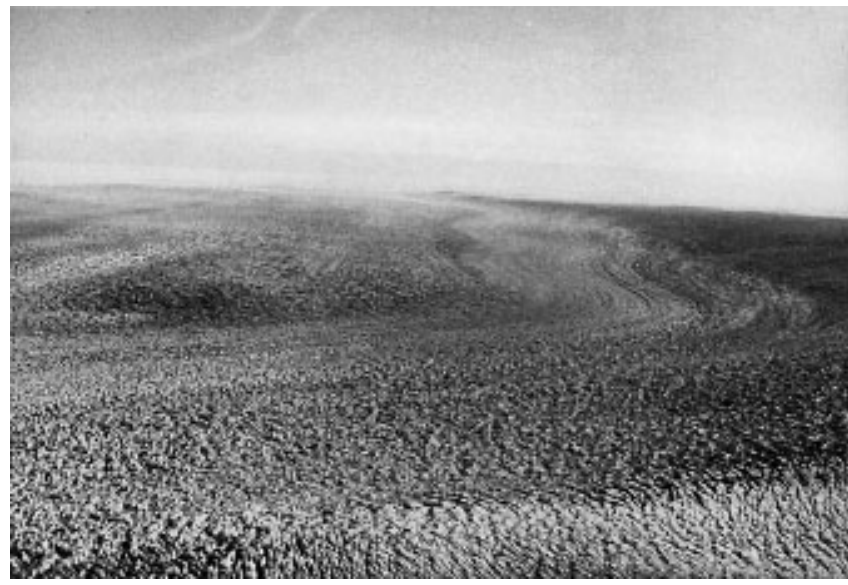

Fig. 1. Jakobshavn Isbre, view to east up South Ice Stream towards source area on the inland ice cap. Focused "Central Ice Stream" with wide, heavily crevassed, marginal zones on both sides (Gro96 H5-27). state) of the ice. Using an approach similar to structural geology which allows the deduction of kinematics and dynamics from structural patterns, we characterize and compare continuously fast-moving ice and surging ice, based on video and photographic imagery of Jakobshavn Isbræ, Greenland, and Bering Glacier, Alaska, U.S.A.

Jakobshavn Isbræ, an outlet glacier of the Greenland ice sheet reaching the west coast, at $69^{\circ} 10^{\prime} \mathrm{N}, 50^{\circ} \mathrm{W}$, is the continuously fastest moving glacier on Earth. The ice stream flows at a mean velocity of $20.6 \mathrm{~m} \mathrm{~d}^{-1}\left(7.5 \mathrm{~km} \mathrm{a}^{-1}\right)$ at the ter-

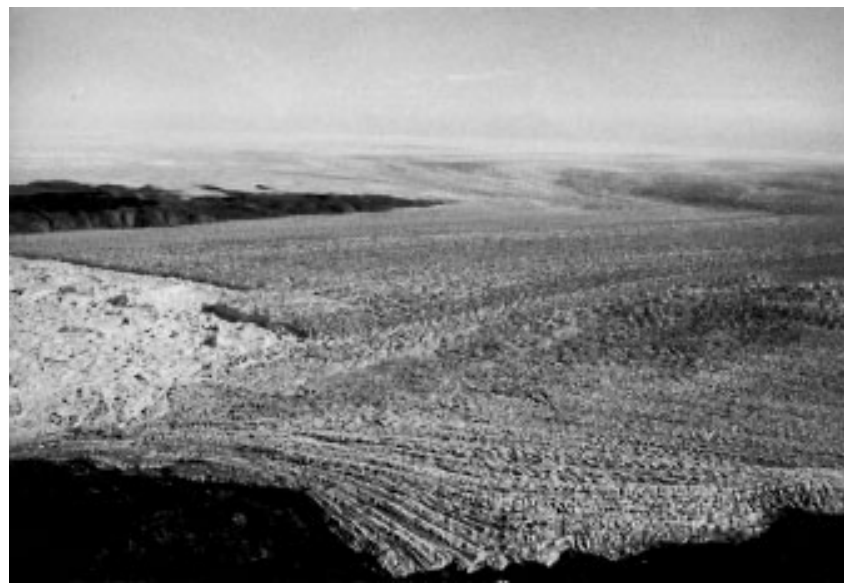

Fig. 2. Terminal part of Jakobshavn Isbre, view to northnortheast. To right, the junction of North and South Ice Streams is visible below a large icefall; to left, the floating part of the glacier, the calving front and the innermost part of the ice fjord can be seen ( Gro96 H5-17). 


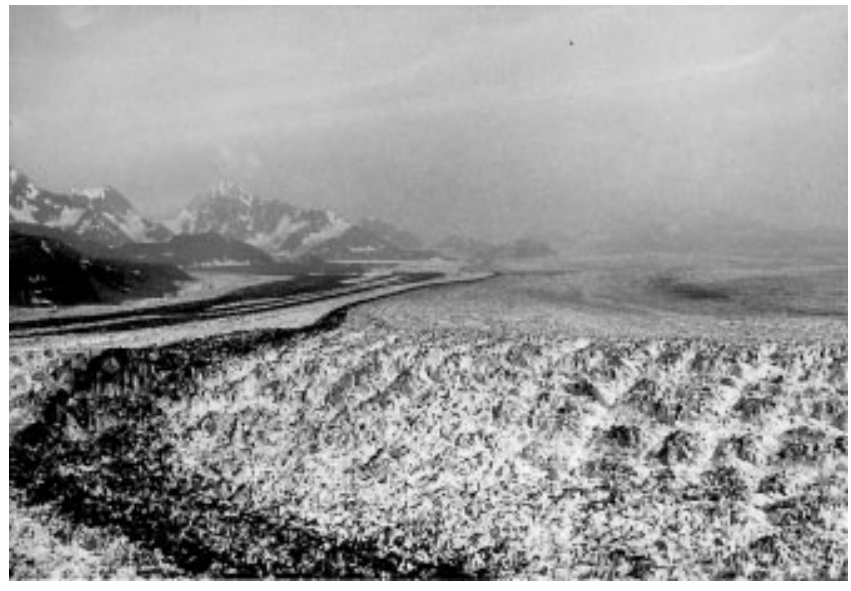

Fig. 3. View up Bering Glacier during late surge stage in August 1995. The surge first started in the foreground, below the Khitrov Hills, in Fune 1993 (B95 9-28).

minus (Pelto and others, 1989). Surprisingly, velocity does not vary seasonally (Echelmeyer and Harrison, 1990). Jakobshavn Isbræ drains an area amounting to $6.5 \%$ of the total area of the Greenland ice sheet (Echelmeyer and others, 1991). The main "South Ice Stream" follows a deep subglacial trough reaching $1500 \mathrm{~m}$ below sea level (Clarke and Echelmeyer, 1996), its surface is characterized by heavy crevassing over a length of $80-100 \mathrm{~km}$. About $12 \mathrm{~km}$ upstream from the terminus, right at the grounding zone, the shorter "North Ice Stream" joins (Figs 1 and 2). The floating ice tongue terminates in a calving front that releases huge icebergs which fill up the $43 \mathrm{~km}$ long Jakobshavn Isfjord completely (Fig. 2), because larger icebergs are grounded on a shoal at the mouth of the fjord, blocking the exit into Disko Bay near Ilulissat (Jakobshavn).

Bering Glacier is a large piedmont glacier in southern Alaska; its ice front stops short of the Gulf of Alaska, at $60^{\circ} 05^{\prime} \mathrm{N}, 143^{\circ} 30^{\prime} \mathrm{W}$, where it calves into a series of proglacial lakes. Together with Bagley Ice Field, from which it originates, it forms the largest glacier of North America, about $200 \mathrm{~km}$ long and $13 \mathrm{~km}$ wide. Bering Glacier is known to surge quasi-periodically, every 20-25 years (cf. Post, 1972; Molnia and Post, 1995). We observed the most recent surge which started in June 1993 and lasted at least through August 1995 (Herzfeld and Mayer, 1997; Herzfeld, 1998) (Fig. 3). During a surge, the glacier's velocity reaches about 100 times its normal velocity. The maximum velocity measured in the 1993-95 surge was $88 \mathrm{~m} \mathrm{~d}^{-1}\left(32.12 \mathrm{~km} \mathrm{a}^{-1}\right)$.

Our interest in these two glaciers focuses on the kinematics of fast-moving ice and the dynamics of large glaciers and ice streams. Here we present a comparison of structural features in continuously fast-moving ice (Jakobshavn Isbræ) and in intermittently fast-moving ice (Bering Glacier during the 1993-95 surge). Due to their sheer size it is practically impossible to cover these glaciers with traditional glaciological and geophysical measurements. However, a fair amount of data, such as velocities, ice thicknesses and temperatures, have been collected on parts of Jakobshavn Isbræ, whereas hardly any such data are available from Bering Glacier. This investigation is based on remote-sensing data: aerial photographs and video images which are analyzed for structural features on the ice surface. The images are georeferenced using global positioning system (GPS) measurements for mapping. Characteristic structural patterns are identified and classified, then mapped in structural provinces over each glacier's area. Here we present the principles of the approach, the observational basis of the ice-surface classification, characteristic structural patterns of Jakobshavn Isbræ and Bering Glacier and an interpretation of their different dynamics. As figures we present reproductions of $35 \mathrm{~mm}$ slides, rather than video frames, because of their higher resolution.

\section{DATA COLLEGTION}

During two survey flights in August 1996 we collected video data and $35 \mathrm{~mm}$ slides over the entire area of Jakobshavn Isbræ using GPS measurements for georeferencing. Additional photographs and videos were taken during deployment and pickup of our field party in May and June 1997 during expedition MICROTOP'97 (Herzfeld and others, 2000a). The videos were taken at a constant look angle normal to the flight direction.

The Bering Glacier data also consist of aerial photographs and video images collected during the course of the surge over three field seasons in June 1993, July 1994 and August 1995. In 1993 individual GPS positions were obtained as reference points, while in the following years GPS positions were registered throughout the survey flights.

The video scenes were analyzed on a Sun workstation. An automated geostatistical surface-classification system, including deterministic and neural-network-based decision algorithms was developed and applied to video scenes from Bering Glacier (Herzfeld and others, 1996; Zahner, 1996; Herzfeld, 1999).

\section{APPLICATION OF STRUGTURAL GLAGIOLOGY IN ICE-SURFACE GLASSIFICATION}

One of the objectives of the structural-glaciological analysis is an extension of the automated geostatistical (ice) surface-classification system (Herzfeld and Higginson, 1996) to ice surfaces from different types of glaciers (and different types of data, cf. Herzfeld and others, 2000b). The aim of ice-surface classification is to discriminate ice-surface types quantitatively and automatically. In the analysis of high-resolution surface-roughness data from Jakobshavn Isbræ drainage basin, the classes are morphological provinces (Herzfeld and others, 2000a). However, in this paper, the classes are crevasse provinces characteristic of certain strain states, which in turn are indicative of the history and present state of dynamics. The core of the geostatistical classification system is the composition of feature vectors, on which deterministic decision algorithms or neural networks operate, resulting in the association of an object class (Herzfeld and Higginson, 1996; Zahner 1996; Herzfeld and others, 1996). The entire classification approach is based on the ability of a glaciologist (or geologist) to discriminate strain states by visual inspection. Since both the deterministic decision and the neural-network association simulate human decision patterns, writing an intelligent computer program requires an intelligent concept which can then be translated into algorithms.

In our case, the classification system should be able to distinguish typical crevasse patterns of a surging glacier from typical patterns of a fast-moving ice stream, and, more specifically, distinguish classes of one-directional, two-direc- 
tional, en-échelon systems, and extensional from compressional and shear systems to give a few examples of elements used in structural analysis in geology. In the context of the classification system, the analysis here demonstrates that characterization (and hence classification) of surface provinces is possible, and provides the necessary description of prototypes of crevasse patterns in a form that lends itself to translation into algorithms.

An alternative approach, and one that would be closer to the traditional school of geophysical glaciology, would entail the derivation of systems of differential equations to capture the principles of dynamics of surging versus continuously fast-flowing ice, then simulation of surface patterns and comparison with the observed. In our experience, the differential-equations approach requires too much simplification of the complexity and richness of forms observed in fast-moving ice, or prohibitively many boundary conditions or mathematical cases. In the geostatistical classification system, the complexity of form or expression of a given state is met at the stage of system development (calibration of the deterministic decision algorithm in the characterization step, or training of the neural network). The application of the final system, however, is fast and robust towards different expressions of principally the same type. For instance, in an application of the connectivistic approach to geostatistical classification of crevasse patterns from the Bering Glacier surge using video images, the system classified $97 \%$ of previously unseen video scans correctly (based on about 10000 images).

While the individual sections below onJakobshavn Isbræ and Bering Glacier provide characteristic descriptions of different surface provinces and typical crevasse patterns (ergo strain states) of each type of glacier, the section on comparison provides discrimination criteria between the two types of glaciers.

In summary, in the context of geostatistical surface classification, the present paper provides the necessary basis for automation, in addition to being a contribution to structural glaciology in its own right.

\section{STRUGTURAL ANALYSIS OF GLACIER SURFACES}

On the surface of a glacier mainly brittle-deformation structures and some ductile-deformation features are seen. We apply principles and techniques from structural geology to analyze and interpret the dominant brittle-deformation structures. From aerial photographs and video images, typical structural patterns are identified and defined. Criteria for the discrimination of different patterns are strike direction, spacing and width of crevasses or faults as well as degree of complexity of the patterns, i.e. number of constituent sets of faults and their directional relationships (angles, interferences). The glacier area may be classified with respect to these patterns and segmented into structural provinces. The ice in each province represents a particular strain state (Herzfeld and Mayer, 1997). Strain histories can be reconstructed to some degree using cross-cutting and overprinting relationships of structures. Applying the mechanical principles of stress-strain relationships and principal planes of stress, the stress field that produced the observed fault pattern can be reconstructed from the types and orientations of faults. Along the same lines of thought stress-field histories may be deduced from strain histories in cases where we have repeat observations, such as for Bering Glacier.

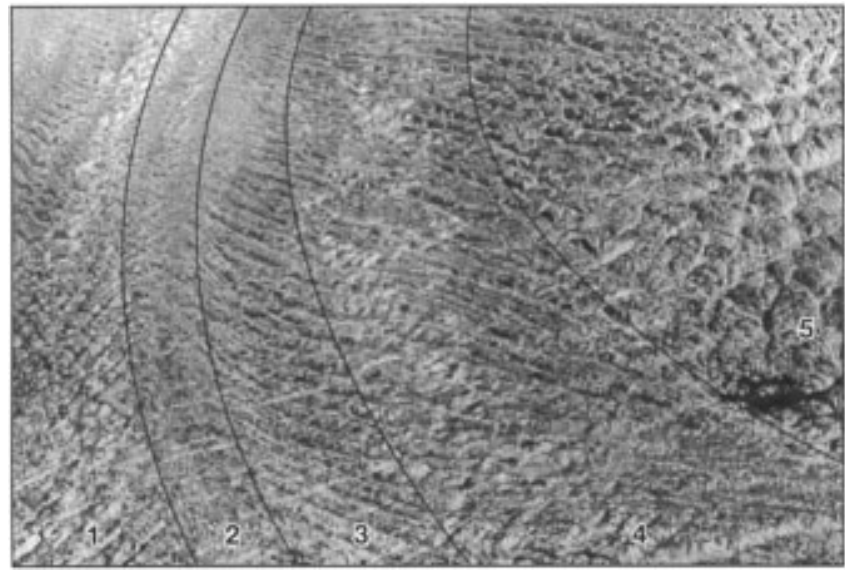

Fig. 4. Fakobshavn Isbre South Ice Stream, overview of marginal zone of the core of the focused ice stream, view in flow direction; structural zones from center (left) to margin (right): (1) closed compressional and conjugate shear faults; (2) very smooth surface with pervasive shear deformation; (3) closed conjugate shear faults with one dominant direction curving into flow direction towards center; (4) closed conjugate shear faults; and (5) slightly open extensional crevasses in multiple directions (Gro96 U5-22).

\section{GREVASSE PATTERNS OF JAKOBSHAVN ISBRÆ}

The entire area of Jakobshavn Isbræ and its margins is characterized by a heavily crevassed surface (Fig. 1). Crevasses are generally arranged in typical patterns defined by shape, direction, spacing, width and a hierarchy of complexity. The dif-

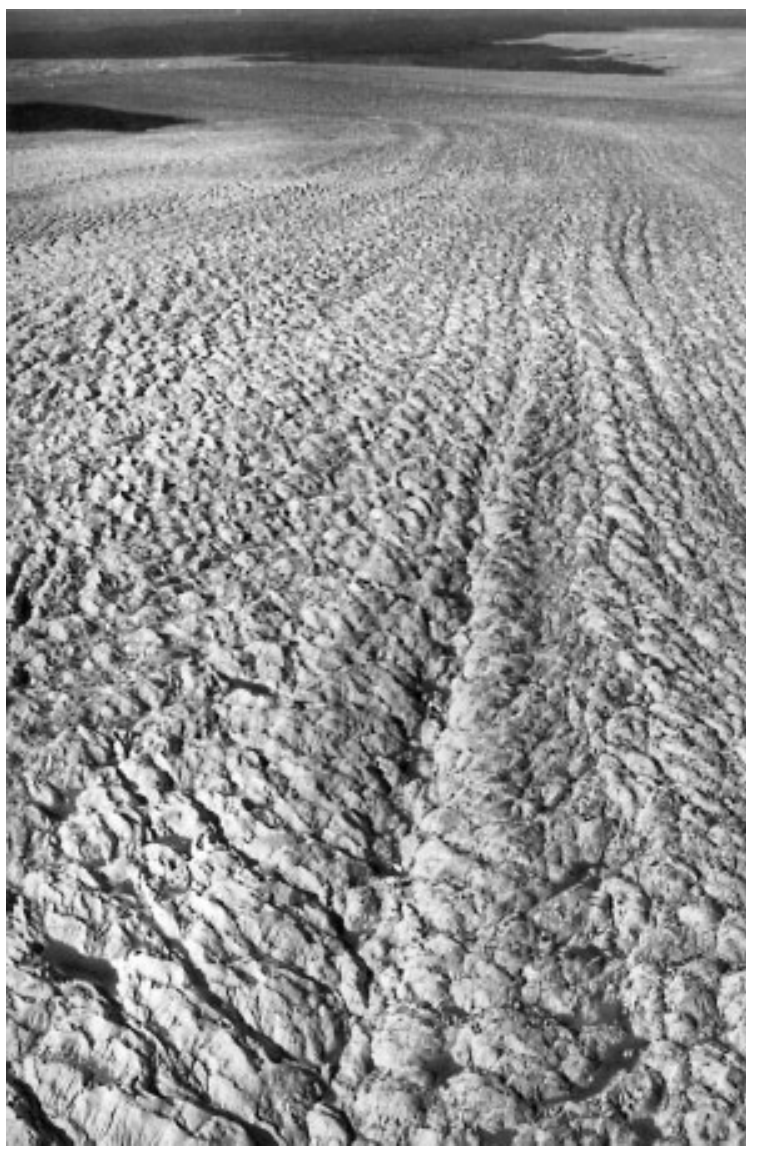

Fig. 5. Jakobshavn Isbre South Ice Stream, view down the centerline: closed, compressional and conjugate, shear faults ( Gro96 H14-38). 


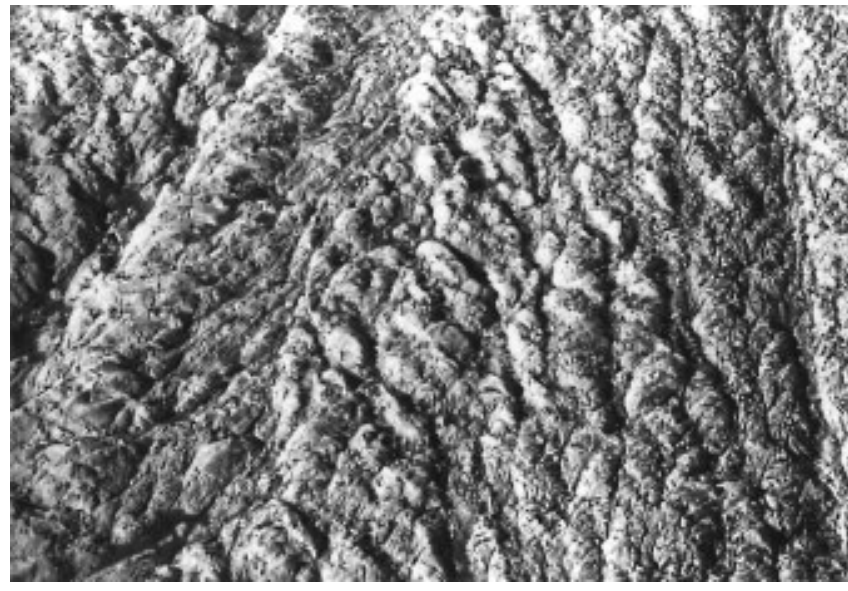

Fig. 6. Jakobshavn Isbre South Ice Stream, close-up view of center ( Gro96 H14-39).

ferent patterns are mostly regionally coherent, in distinct zones arranged normal to the flow direction. The patterns are presented in a succession of zones from the center of the ice stream to the margins (Fig. 4). The center (zone l) is characterized by an array of closed compressional and shear structures (faults) resulting in a relatively smooth surface (Figs 4 and 5). Either side of the central zone is a narrow zone of very smooth surface with pervasive shear deformation (zone 2). All structures are completely closed (Fig. 4). Then follows a zone of closed, conjugate, shear faults with one direction dominating and curving into the flow direction towards the center (zone 3). This is followed by a zone of lessdistorted, more-symmetrical, conjugate shear faults, which are also closed (zone 4). The next zone of slightly open, extensional, structures (crevasses) in multiple directions (zone 5) forms the transition from the core of the ice stream to the wide marginal zones on both sides (zone 6, not shown in Fig. 4, but visible in Fig. 1). These marginal zones are generally characterized by variably open extensional and shear structures (crevasses) (Figs 1, 6, 7 and 8). Locally, in zone 6, a number of different patterns can be distinguished differing in number of directions and width of crevasses. Their spatial distribution is dependent on distance from the focused core of the ice stream and on location relative to bends in the ice stream. In the terminology used by Echelmeyer and others (1991) only zones 1-4 are termed "ice stream". Their own velocity measurements,

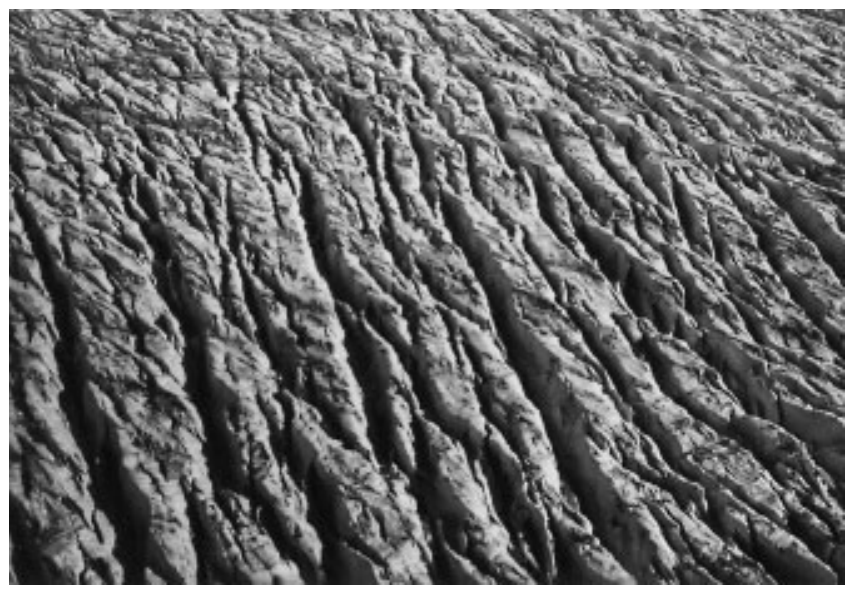

Fig. 7. Jakobshavn Isbra South Ice Stream, southern, outer, marginal zone: wide-open, extensional, crevasses with one dominant direction (Gro96 H14-13).

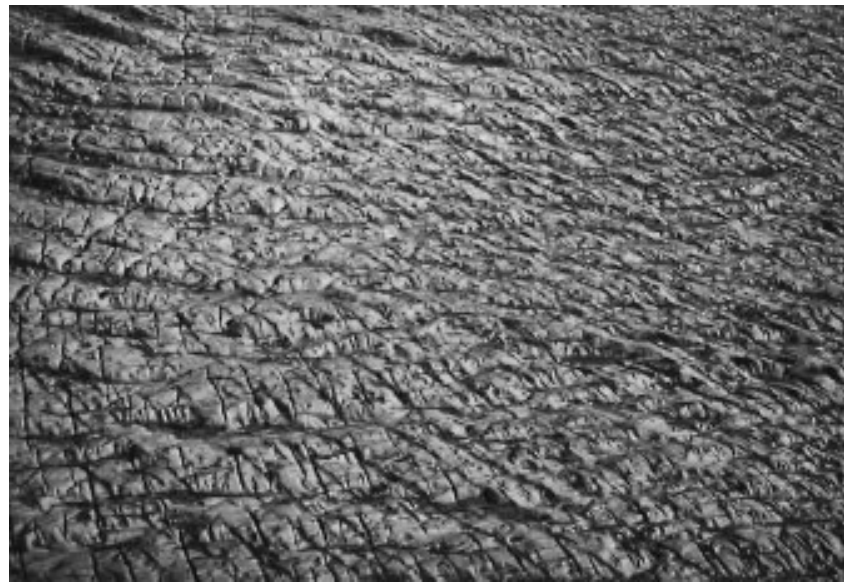

Fig. 8. Jakobshavn Isbre South Ice Stream, southern, outermost, marginal zone: just-opening, extensional, crevasses with one dominant direction overprinting older closed crevasses in multiple directions ( Gro96 H14-16).

however, indicate high velocities through zones 1-6 (cf. Echelmeyer and Harrison, 1990). From our observations, and in agreement with those velocity measurements, we consider the entire fast-moving part including the wide, heavily crevassed, marginal zones (zones 1-6) the ice stream; zones 1-4 we call the "focused core of the ice stream".

Some other locally characteristic patterns exist such as the huge serac staircase of the icefall at the junction of North Ice Stream and South Ice Stream (Figs 1 and 2) and the seam structure from this junction to the calving front along the suture of the two ice streams (Figs 2 and 9).

The center of the ice stream (zone 1) is also characterized by equally sized parallel ridges (10 m wide, $4 \mathrm{~m}$ high) that run in the direction of flow (Figs 1, 5 and 6) and may serve as "flowline tracers" (Echelmeyer and others, 1991). Similar, but much wider, features on Antarctic ice streams ("flow stripes") have recently been described and modelled by Gudmundsson and others (1998) as disturbances from the bed. The ridges on Jakobshavn Isbræ are certainly not an expression of subglacial topography, they are much too small compared to the ice thickness of about $2500 \mathrm{~m}$. We observed that the ridges on Jakobshavn Isbræ are separated by shear bands forming narrow troughs on the surface (Figs 5 and 6), which supports our interpretation that these fea-

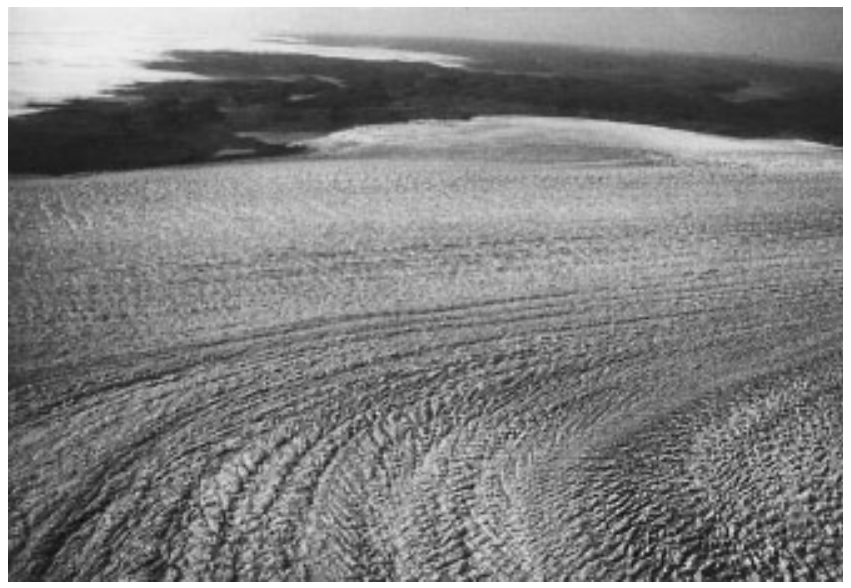

Fig. 9. Jakobshavn Isbre, junction of North and South Ice Streams, view to the southwest down the North Ice Stream: clear shear pattern in foreground at bend, seam line runs east-west (left to right) through center of picture (Gro96 H7-24). 


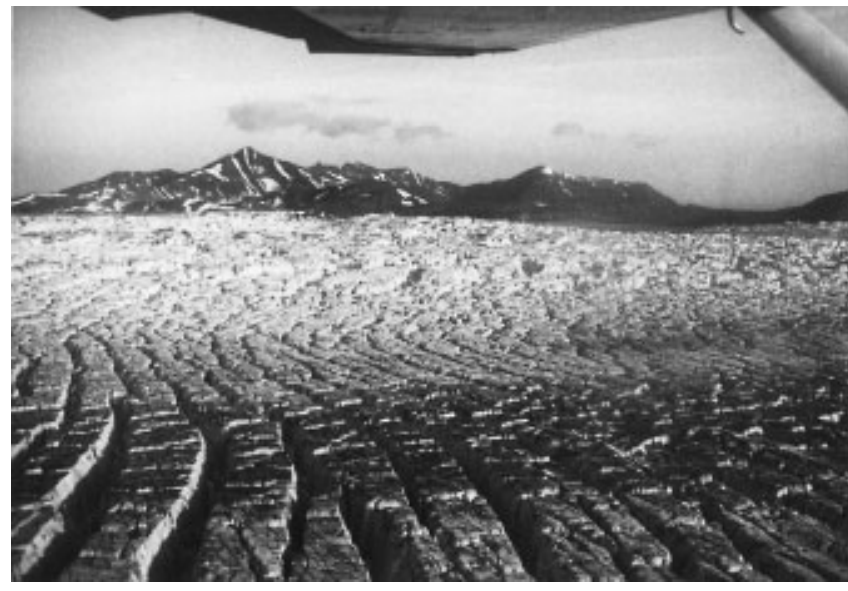

Fig. 10. Bering Glacier in Fuly 1994: wide-open, extensional, two-directional, crevasses with one dominant wavy direction (B94 17-12).

tures are a consequence of transverse velocity gradients. We consider these ridges and their repetitive pattern as an expression of an autonomous dynamical system. Continuous rapid flow of a confined ice stream in the presence of transverse velocity gradients leads to sheet flow of vertical slices separated by shear bands.

A particular property of most structural patterns observed on Jakobshavn Isbræ is their hierarchical structure. Deformation breaks the ice mass into blocks of similar size, in groups with larger central blocks and smaller surrounding blocks. Each group has one central block and about the same number of adjacent secondary blocks, and all groups are of about equal size. Such grouping occurs in zones 1, 3, 4 and 5 as well as parts of zone 6 (see Figs 4, 5, 8 and 9). This major morphogenetic component seems to be attributable to the fact that the driving force of the glacier acts continuously on the material ice, which is constantly deformed breaking into blocks at increments of time. Although it is not known exactly when these small-scale deformation events happen, they appear to occur in constant time and distance intervals.

\section{GREVASSE PATTERNS OF BERING GLACIER}

In the course of the recent surge the normally mostly smooth,

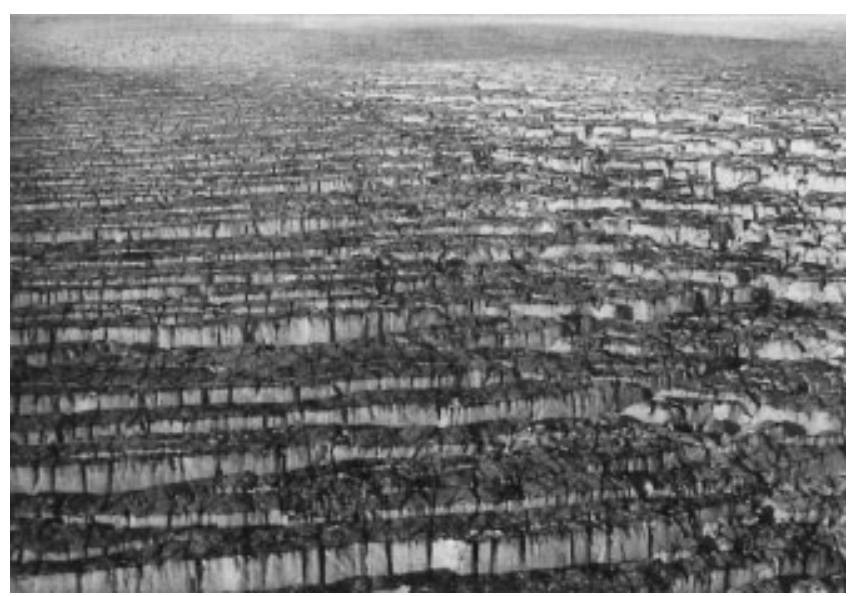

Fig. 11. Central Bering Glacier in fuly 1994: long, wide-open, parallel crevasses overprinting several older closed crevasses; boundary to other structural zone on the right (B94 17-16).

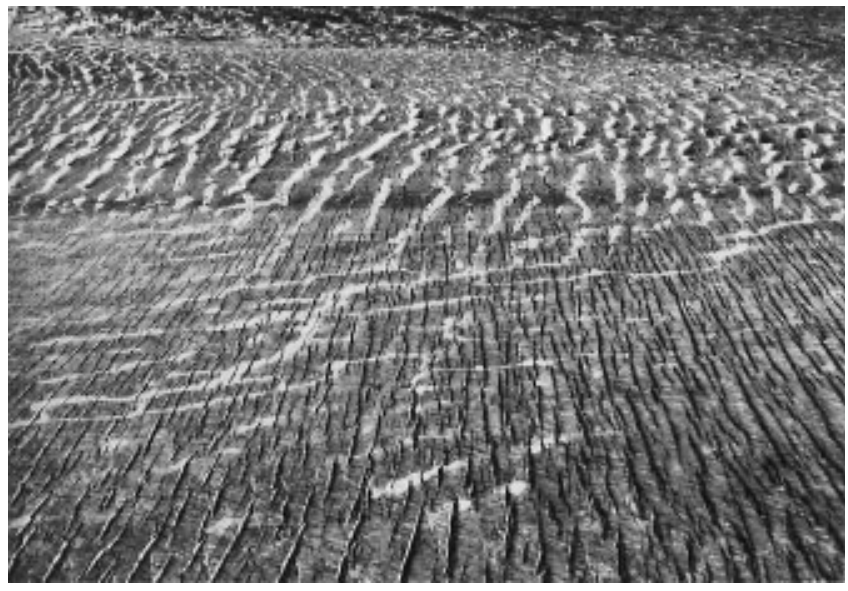

Fig. 12. Upper Bering Glacier in August 1995: three distinct structural zones (B95 1-28).

surface of central and upper Bering Glacier was completely broken up into a single, huge, heavily crevassed area extending eventually from the ice front far up into Bagley Ice Field (Figs 3 and 10). However, throughout the surge a number of characteristic crevasse patterns distributed over the glacier in distinct fields were recognizable (Figs 10, 11, 12 and 13). An exhaustive documentation of these surge-crevasse patterns and of the development of the surge is given in Herzfeld (1998). Here we present a selected number of surge-crevasse patterns for comparison with the crevasse patterns of Jakobshavn Isbræ. The structures on the surface of surging Bering Glacier are mostly extensional and wide open. Surge crevasses are generally characterized by their sharp edges and overall fresh appearance. One of the most prominent patterns is that of parallel crevasses with one clearly dominating direction of wide-open crevasses (Figs 11 and 14). Twodirectional crevasses, with two approximately orthogonal directions of open extensional crevasses, are typical for the surge and occur in a number of subtypes differing in spacing, width and/or relative age of the two directions (Figs 10, 11 and 13). Wavy crevasses are also common and can be modifications of parallel or two-directional crevasses (Figs 10, 12 and 13). Their wave shape can be explained by velocity differences normal to the flow direction. En-échelon cre-

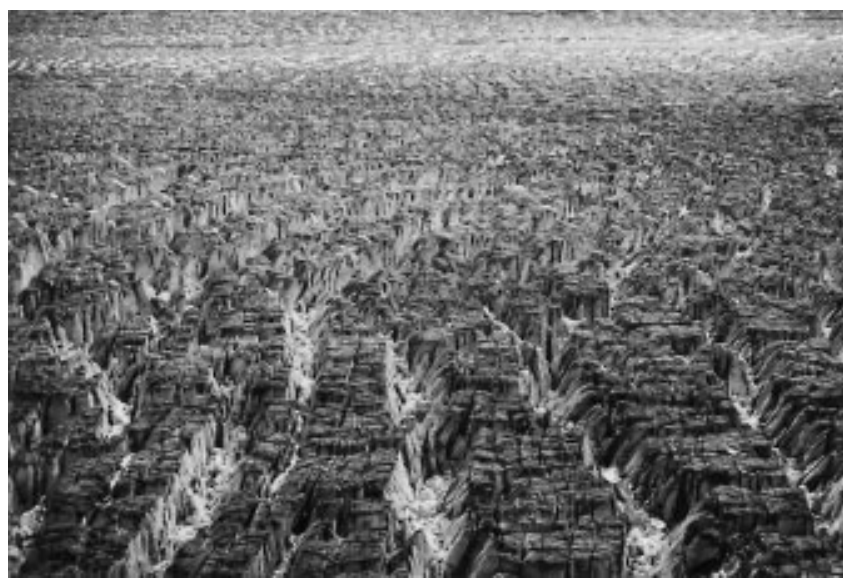

Fig. 13. Central Bering Glacier in August 1995: two-directional crevasses, one direction rejuvenated with wider spacing and transformed to wavy crevasses; highly degraded 1-2 year old surge crevasses (B9510-36). 


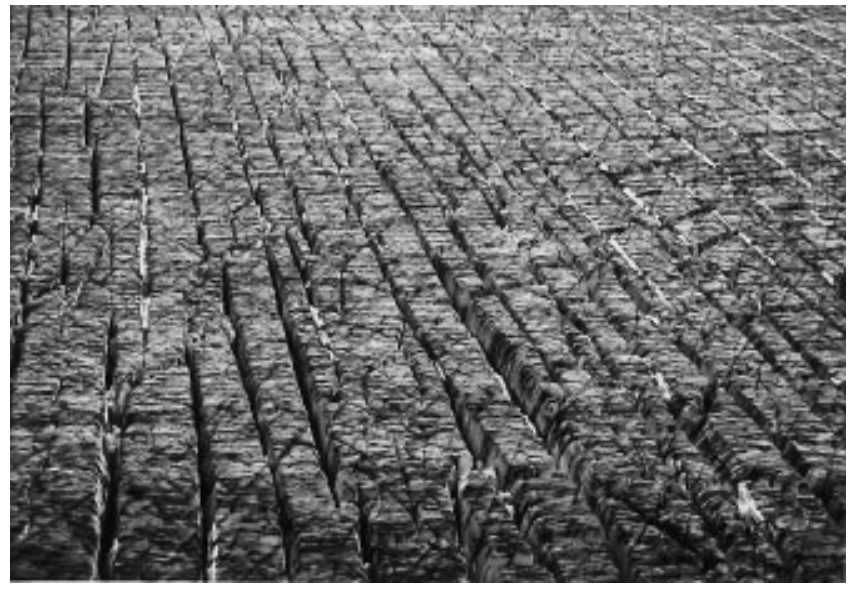

Fig. 14. Central Bering Glacier in August 1995: parallel crevasses, already degraded, cross-cutting older, now-closed, two-directional, crevasses at an oblique angle (B95 10-21).

vasses are typical for areas which are newly affected by the surge or experience a directional change of the stress field (Figs 15 and 16). The stress of the second generation is broken and deflected at the lines of weakness (pre-existing crevasses) forming the en-échelon patterns, which have a characteristic feathery appearance (Fig. 16). Locally, compressional structures such as pressure ridges and wave-like surface undulations occur. During the later stages of the surge, most of the distinct fields of characteristic crevasse patterns revealed a series of overprinted structures containing a record of the changes in stress-field orientation these blocks of ice had experienced (see Figs 10, 11, 12, 13 and 14). An analysis of the

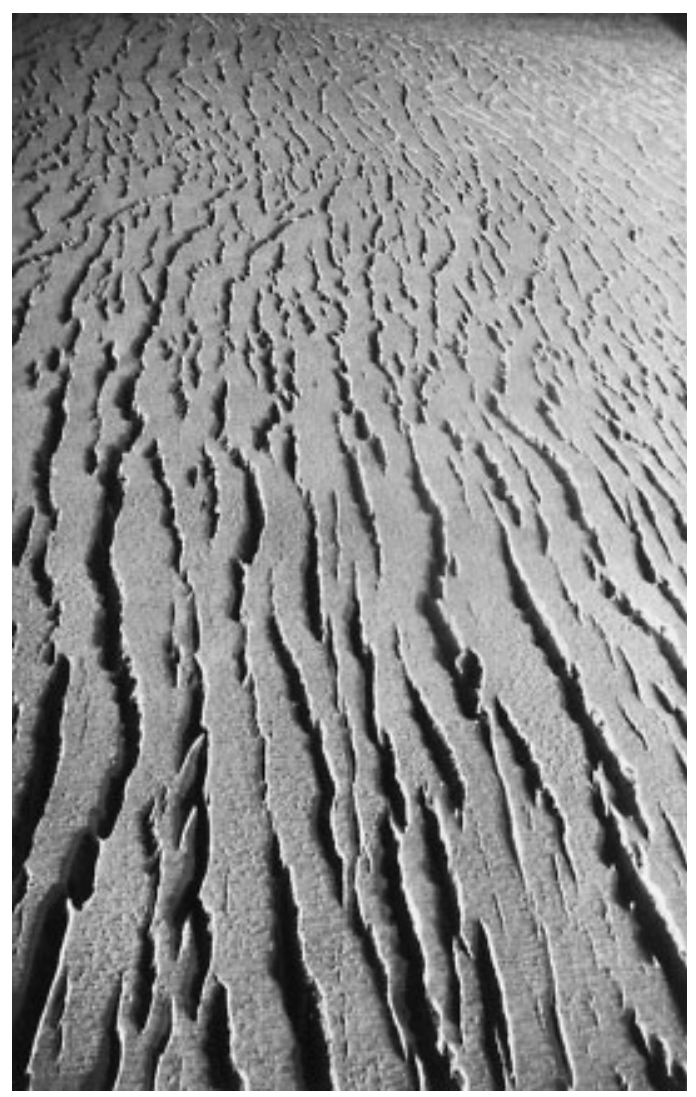

Fig. 15. Upper Bering Glacier in Fuly 1994: fresh, parallel, surge crevasses being modified by en-échelon structures indicating a change in stress-field orientation (B9417-06). advance of the surge along with a structural interpretation is given in Herzfeld and Mayer (1997).

\section{GOMPARISON AND DISGUSSION}

The deformation zones on the surface of Jakobshavn Isbræ display a bilateral symmetry in their succession from the center of the ice stream to the margins. The center is dominated by closed compressional and shear faults, flanked by transitional zones of curved and conjugate shear faults, while the wide marginal zones are increasingly dominated by more or less open extensional crevasses.

The surface of the surging Bering Glacier is dominated by wide-open extensional crevasses arranged in patches of typical patterns of parallel crevasses (mostly normal to the flow direction), two-directional crevasses and wavy crevasses without a bilateral symmetry. The distribution of structural provinces is irregular and rather follows the evolution of the surge: individual "pushes" of the surge and interference with subglacial topography determine their arrangement. Local pushes affect only parts of Bering Glacier. Such provinces of homogeneous surface pattern can be clearly delineated at all (observed) times during the surge.

Some similar patterns occur in the marginal extensional zones of Jakobshavn Isbræ and in Bering Glacier such as certain parallel crevasses overprinting closed older crevasses of various directions (cf. Figs 8 and 14). Also, the "haystack" crevasses of Bering Glacier (Fig. 3; see Herzfeld, 1998) resemble the hierarchical grouping observed in some extensional zones of Jakobshavn Isbræ (Fig. 4, zone 5, upper right corner). However, the crevasses of Jakobshavn Isbræ always feature rounded edges and uneven, weathered and degraded horizontal and vertical surfaces of the ice blocks. This is not only due to erosion, but also a result of the continuous deformation as described earlier. The surge crevasses of Bering Glacier are characterized by sharp undegraded edges; the ice blocks initially feature plane horizontal and vertical surfaces. This aspect is the result of the sudden breakup of a previously undeformed surface. These features then become degraded within a year.

Both glaciers feature heavily deformed fast-moving ice. However, the differences are much greater than the similarities. The different brittle-deformation patterns on the surface define different strain states for different portions of the ice mass (Herzfeld and Mayer, 1997). The strain states, their juxtaposition and development in time and space are indicative of the kinematics of the glacier. On Jakobshavn Isbræ the spatial distribution of structural provinces is in a near steady state. Although the ice itself moves downstream rather fast, the arrangement and localization of deformation zones is stable in space (analogous to the distribution of rapids, waterfalls and lakes in the course of a river) because the boundary conditions which determine the stress field such as subglacial topography, bottom friction and surface topography do not change. Nevertheless, the ice is transported through different zones and keeps a record of the succession of deformations it experiences; it accumulates strain and keeps structures once acquired which are overprinted and modified when it enters a new zone with a different stress regime. A good example can be seen in the outermost marginal zone (Fig. 8) where the acting stress field produces just-opening extensional crevasses with one dominant direction in ice that has experienced many phases 


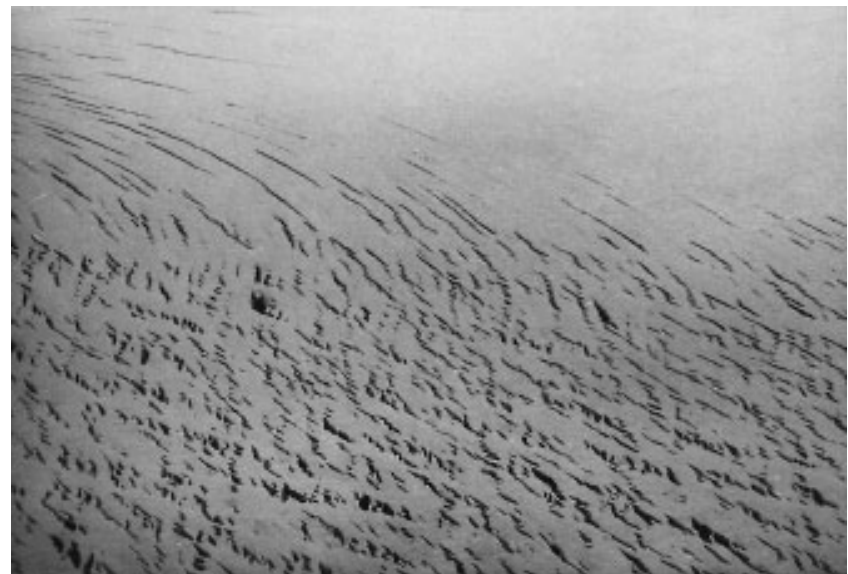

Fig. 16. Bagley Ice Field in August 1995: fresh, feathery, enéchelon crevasses with relatively wide holes, first manifestation of surge in this area (B9512-11).

of previous deformation in different stress fields visible in several sets of closed crevasses in various directions.

Jakobshavn Isbræ may be considered an autonomous dynamical system, because the ice flow does not vary with time. This has been observed by Echelmeyer and Harrison (1990) from velocity measurements and is also evident in the strain field as described above.

Bering Glacier, on the contrary, is a time-dependent (i.e. non-autonomous) system; the catastrophic event of the surge induces a sudden change in system variables, which is visible, for instance, in the sudden appearance of fields of clear-cut crevasses in a previously smooth ice surface created by flow at near-constant velocity. The boundary conditions change suddenly, e.g. bottom friction changes, the confining presence of surrounding ice changes, the volume of liquid water changes with the onset and through the duration of the surge. The ice accelerates to roughly 100 times its normal velocity. So, although we can recognize well-defined strain provinces on the surface of the surging Bering Glacier and ice moves through different stress fields, these stress fields are not stable in space over longer periods of time due to the changing boundary conditions. Therefore the distribution of strain provinces changes continuously throughout the surge. An important aspect here is the virtual disappearance of the lateral confining pressure as the surge wave travels up-glacier and down-glacier. This explains the obvious predominance of extensional deformation with wide-open crevasses during the surge.

In summary we can state that structural analysis of the surface structures of glaciers provides information on the kinematics and dynamics of these glaciers. Strain states and strain histories may be deduced. Aerial imagery from small aircraft is the data source that is acquired fastest and areally most complete for such a structural analysis. A comparison of structures on the surfaces of the continuously fast-moving
Jakobshavn Isbræ and the surging Bering Glacier reveals fundamental differences that can ultimately be attributed to the situation of a time-independent flow system in continuously fast-moving ice versus the catastrophically changing flow system in surging ice.

\section{ACKNOWLEDGEMENTS}

We would like to thank our pilots T. Rose fromWildeshausen, J. Wilken of Grønlandsfly, and G. and S. Ranney of Cordova Fishing and Flying. Work was supported in part through the U.S. Geological Survey Bering Glacier Research Project in 1994, the U.S. National Aeronautics and Space Administration Office of Polar Programs grant NAGW-3790 and by Deutsche Forschungsgemeinschaft through a Heisenberg Fellowship to U.C.H. and grant He1547/4.

\section{REFERENGES}

Clarke, T. S. and K. Echelmeyer. 1996. Seismic-reflection evidence for a deep subglacial trough beneath Jakobshavns Isbræ, West Greenland. F. Glaciol., 42(141), 219-232.

Echelmeyer, K. and W. D. Harrison. 1990. Jakobshavns Isbræ, West Greenland: seasonal variations in velocity - or lack thereof. f. Glaciol., 36(122), 82-88.

Echelmeyer, K., T. S. Clarke and W. D. Harrison. 1991. Surficial glaciology of Jakobshavns Isbræ, West Greenland: Part I. Surface morphology. $\mathcal{F}$. Glaciol., 37(127), 368-382.

Gudmundsson, G. H., C. F. Raymond and R. Bindschadler. 1998. The origin and longevity of flow stripes on Antarctic ice streams. Ann. Glaciol., 27, $145-152$.

Herzfeld, U. C. 1998. The 1993-1995 surge of Bering Glacier (Alaska) - a photographic documentation of crevasse patterns and environmental changes. Trierer Geographische Studien 17.

Herzfeld, U. C. 1999. Geostatistical interpolation and classification of remote sensing data from ice surfaces. Int. 7. Remote Sensing, 20(2), 307-327.

Herzfeld, U. C. and C.A. Higginson. 1996. Automated geostatistical seafloor classification - principles, parameters, feature vectors, and discrimination criteria. Comput. Geosci., 22(1), 35-52.

Herzfeld, U. C. and H. Mayer. 1997. Surge of Bering Glacier and Bagley Ice Field, Alaska: an update to August 1995 and an interpretation of brittledeformation patterns. F. Glaciol., 43(145), 427-434.

Herzfeld, U. C., O. Zahner, H. Mayer, C. A. Higginson and M. Stauber. 1996. Image analysis by geostatistical and neural-network methodsapplications in glaciology. In Guyenne, T. D., ed. Proceedings of the Fourth Circumpolar Symposium on Remote Sensing of the Polar Environments, 29 April1 May 1996, Lyngby, Denmark. Noordwijk, European Space Agency. ESA Publications Division, 87-91. (ESA SP-391.)

Herzfeld, U. C., H. Mayer, W. Feller and M. Mimler. 2000a. Geostatistical analysis of glacier-roughness data. Ann. Glaciol., 30 (see paper in this volume).

Herzfeld, U. C., M. Stauber and N. Stahl. 2000b. Geostatistical characterization of ice surfaces from ERS-1 and ERS-2 SAR data, Jakobshavn Isbræ, Greenland. Ann. Glaciol., 30 (see paper in this volume).

Molnia, B. F. and A. Post. 1995. Holocene history of Bering Glacier, Alaska: a prelude to the 1993-1994 surge. Phys. Geogr., 16(2), 87-117.

Pelto, M. S., T. J. Hughes and H. H. Brecher. 1989. Equilibrium state of Jakobshavns Isbræ, West Greenland. Ann. Glaciol., 12, 127-131.

Post, A. 1972. Periodic surge origin of folded medial moraines on Bering piedmont glacier, Alaska. 7. Glaciol., 11 (62), 219-226.

Zahner, O. 1996. Automatische Oberflächenklassifikation mit neuronalen Netzen - Erprobung eines konnektionistischen Verfahrens an Videodaten vom Beringgletscher/Alaska. (Diplom thesis, Universität Trier, Fachbereich VI - Geographie/Geowissenschaften.) 